\title{
Microglanis pataxo, a new catfish from southern Bahia coastal rivers, northeastern Brazil (Siluriformes: Pseudopimelodidae)
}

\author{
Luisa M. Sarmento-Soares*, Ronaldo F. Martins-Pinheiro**, \\ Arion T. Aranda*** and Carine C. Chamon****
}

A new pseudopimelodid catfish of the genus Microglanis, collected in small rivers at the lower and middle Peruípe, middle Jucuruçu and Cahy basins, in the southeastern coast of the Bahia state, is described. The new species has a comparatively high number of anal fin proximal radials, 12 , shaped as thin tubes, the last one bearing a laminar extension; a pectoral fin spine with a bony point and with a smaller number of serrations on its posterior border; seven pleural ribs and a narrow head width. We provide information on the external morphology and also on some osteological features for the new species. A key to species is presented for the coastal drainages between Rio de Janeiro and Bahia states.

É descrito um novo pseudopimelodídeo do gênero Microglanis, coletado em riachos tributários das bacias do baixo e médio rio Peruípe, médio rio Jucuruçu e rio Cahy, na costa sudeste do estado da Bahia. A nova espécie tem comparativamente um maior número de radiais proximais da nadadeira anal, 12, em formato de finos tubos, sendo que o último elemento possui uma extensão laminar; nadadeira peitoral com extremidade óssea e com pequeno número de serrilhas no bordo posterior; sete costelas pleurais e cabeça estreita. São fornecidas informações sobre a morfologia externa bem como sobre alguns aspectos da osteologia da nova espécie. É apresentada uma chave para as espécies nas drenagens costeiras entre os estados do Rio de Janeiro e Bahia.

Key words: Neotropical, Systematics, Freshwater, South America.

\section{Introduction}

The genus Microglanis comprises catfishes that never grow to a size larger than $80 \mathrm{~mm}$ (Shibatta, 2003a). Those catfishes have a flattened large head, spines and fin-rays, a complete lateral line, but with pores distinct only on anterior parts of the body and on the head (Mees, 1974). They are beautifully colored fishes, with a characteristic light band running across the nape and alternate light and dark blotches over the body.

The genus Microglanis was proposed by Eigenmann (1912) to include small pimelodid catfishes, rarely attaining more than $70 \mathrm{~mm}$ in standard length. Shibatta (1998) included Microglanis in the small family Pseudopimelodidae, containing catfishes with a wide mouth, small eyes without free orbital margin, and short barbels. The genus is considered monophyletic on the basis of putative autapomorphic features such as premaxillary bands of teeth with lateral margin rounded, mesocoracoid arch filamentous, and body size smaller than $80 \mathrm{~mm}$ (Shibatta, 2003a). Microglanis has the widest distribution within the family Pseudopimelodidae (Shibatta, 2003b), with fourteen known species ranging from the Guianas, Venezuela, western slope of the Andes in Ecuador and Peru, to the Rio de La Plata basin in Argentina. The northern species are M. iheringi Gomes, 1946, from the río Turmero, near Turmero, Aragua, Venezuela; $M$. pellopterygius Mees, 1978, from a tributary of the río Aguarico

\footnotetext{
*Setor de Ictiologia, Departamento de Vertebrados, Museu Nacional, Quinta da Boa Vista, 20940-040 Rio de Janeiro, RJ, Brazil. e-mail: luisa@nossacasa.net

**Projeto BIOBAHIA. Alto do rio do peixe pequeno, quadra 2, lote 14, Cumuruxatiba, 45983-000 Prado, BA, Brazil. e-mail: ronaldo@nossacasa.net

***Curador Técnico da Coleção de Simulídeos/LSO. Convênio FAPERJ/FIOCRUZ. Laboratório de Referência Nacional em Simulídeos e Oncocercose. Pavilhão Carlos Chagas, $4^{\circ}$ andar, sala 07. Instituto Oswaldo Cruz/FIOCRUZ. Rio de Janeiro, RJ, Brazil. e-mail: arion@ioc.fiocruz.br

****Setor de Ictiologia, Departamento de Vertebrados, Museu Nacional, Quinta da Boa Vista, 20940-040 Rio de Janeiro, RJ, Brazil. e-mail: carinechamon@yahoo.com.br
} 
in Santa Cecília, Napo, Ecuador; M. poecilus Eigenmann, 1912, from Packeeo Falls, Guyana and French Guiana; M. secundus Mees, 1974, from the Marowijine, Saramacca, Coppename, rio Nickerie and rio Coratijin, in Suriname, rio Rupununi, in Guyana and also from rio Catatumbo, in Colombia; M. variegatus Eigenmann \& Henn, 1914, from a pool in the Vince forest, Ecuador, and M. zonatus Eigenmann \& Alen, 1942, from the rio Morona, upper rio Amazonas basin in Peru. One species, M. ater (Ahl, 1936), is supposedly recorded from freshwater river drainages at central Brazil, a record that is questionable according to Mees (1974), as the type locality is "Mittelbrasilien", with no exact localities known. Shibatta (2003b) states that this species occurs in South America, and the record from Brazil is questionable. The species recorded from southern South America are M. cibelae Malabarba \& Mahler, 1998, from a tributary of the rio Maquiné, between Maquiné and Barra do Ouro, coastal drainages in northeastern Rio Grande do Sul and southern Santa Catarina, Brazil; M. cottoides (Boulenger, 1891), from the rio Camaquã, laguna dos Patos system, Rio Grande do Sul, and also from rio Uruguay basin, Brazil; M. eurystoma Malabarba \& Mahler, 1998, from upper rio Uruguay, Santa Catarina, Brazil, and M. malabarbai Bertaco \& Cardoso, 2005, from a tributary of rio Ijuí, middle rio Uruguay, Rio Grande do Sul, Brazil. One species was recently described for the upper rio Paraná basin, M. garavelloi Shibatta \& Benine, 2005. Microglanis currently includes two species chiefly distributed in the coastal basins of eastern Brazil: Microglanis parahybae (Steindachner, 1880), from the rio Paraíba do Sul and Santa Cruz, Rio de Janeiro, Brazil and M. nigripinnis Bizerril \& Peres-Neto, 1992, from the rio Macacu, Papucaia, Cachoeira do Macacu, Rio de Janeiro, Brazil.

The BIOBAHIA project (Diversity, endemism and biogeography of catfishes in less explored aquatic systems in the extreme southern Bahia) aims to provide an inventory of the freshwater fishes of the hydrographic systems opening to the Atlantic at southern Bahia region. Along with the cooperation of the Museu Nacional and the All Catfish Species Inventory Project, a recent ichthyological survey in northeastern Minas Gerais and southern Bahia rivers was undertaken, revealing a new species of Microglanis, which is described herein.

\section{Material and Methods}

Straight-line measurements were taken point to point under a stereomicroscope with a Mitutoyo digital caliper, and recorded in tenths of a millimeter. Measurements followed Malabarba \& Mahler (1998) except the following: caudal peduncle length: from base of last anal fin ray to base of lower caudal fin unbranched ray; orbital diameter: greatest horizontal dimension of eye ball; snout length: from tip of snouth to anterior border of orbits; and interorbital width: between dorsal margins of eye. Standard length (SL) is expressed in $\mathrm{mm}$ and all other measurements are expressed as percents of standard length, except subunits of the head, which are expressed as percents of head length (HL). Vertebral counts included all rib-bearing centra but do not include any of the anterior, com- plex centrum elements without ribs, and included the compound caudal centrum (PU1+U1) as the last element. The direction of dorsal and pectoral-fin spine serrations are referred to as antrorse, for those pointing away from the base of spine, and retrorse, for those bent towards the base of the spine. Osteological terminology follows Arratia \& Huaquin (1995) and Arratia (2003) and were verified in cleared and stained specimens (c\&s), following the procedures of Taylor \& Van Dyke (1985) or in radiographs (R) of specimens. Osteological information for $M$. cottoides, M. iheringi, M. parahybae, $M$. poecilus, M. variegatus, and M. zonatus were based on radiographs of specimens as listed under comparative material. External morphological data about Microglanis pellopterygius and also complementary information for $M$. iheringi, $M$. poecilus, M. variegatus, and M. zonatus were based on photographs (P). Information about Microglanis ater, $M$. eurystoma, M. malabarbai, M. nigripinnis, and M. secundus were based on literature (Mees, 1974; Bizerril \& Peres Neto, 1992; Malabarba \& Mahler, 1998; Bertaco \& Cardoso, 2005), as no specimens of these species were available for examination.

The following acronyms are used to specify the repositories of material examined: AMNH, American Museum of Natural History, New York; ANSP, Academy of Natural Sciences of Philadelphia, Philadelphia; AUM, Auburn University Museum, Auburn; CAS, California Academy of Sciences, San Francisco; MNRJ, Museu Nacional, Rio de Janeiro; UF, University of Florida Museum of Natural History, Gainesville, and USNM, United States National Museum, Washington, D.C.

\section{Microglanis pataxo, new species \\ Fig. 1}

Holotype. MNRJ 28397 (39.0 mm SL), Brazil, Bahia: Itamarajú, Jundiar creek on road BR-101 after joint with road to Jucuruçu, in the neighbourhoods of the city of Itamaraju $\left(17^{\circ} 01\right.$ ' $35^{\prime \prime} \mathrm{S}$ $\left.39^{\circ} 35^{\prime} 57^{\prime \prime W}\right), 25$ Oct 2004, L.M.Sarmento-Soares, A.T.Aranda, C.C.Chamon \& R.F.M.Pinheiro.

Paratypes. Brazil, Bahia: AMNH 236058 (2, 22.1-27.5 mm SL), UF 148528 (2, 22.2-27.2 mm SL), and MNRJ 28398 (5, 1 c\&s, 22.7-38.0 mm SL) all collected with the holotype. MNRJ 28399 $(1,26.3 \mathrm{~mm} \mathrm{SL})$; Nova Viçosa, tributary of rio Peruípe on road BR418 , after $14 \mathrm{~km}$ from BR-101 in direction to Caravelas (17²50'24"S $39^{\circ} 42^{\prime} 01$ "W), 22 Oct 2004, same collectors as the holotype. MNRJ 28400 (1, $26.2 \mathrm{~mm} \mathrm{SL})$; Caravelas; unnamed stream on BR-418, about $27 \mathrm{~km}$ from BR-101 in direction to Caravelas, below the bridge crossing (17\%46’34"S 39³6'09"W), 22 Oct 2004, same collectors as the holotype. ANSP 180651 (2, 23.1-23.5 mm SL), and MNRJ 28401 (4, 1 c\&s, 23.9-36.4 mm SL), Prado, rio Palmares on road Guarany-Corumbau, in direction to Corumbau after joint with the road to the mouth of rio Cahy (16 $\left.57^{\circ} 48^{\prime \prime} \mathrm{S} 39^{\circ} 16^{\prime} 33^{\prime \prime} \mathrm{W}\right), 24$ Oct 2004, same collectors as the holotype. MNRJ 28402 (2, 23.8$30.8 \mathrm{~mm} \mathrm{SL}$ ), Prado, rio Palmares on road from Guarany to Corumbau, near Palmares (16056'25"S 39¹9'48"W), 24 Oct 2004, same collectors as the holotype. AUM $42221(2,23.1-23.2 \mathrm{~mm}$ SL), and MNRJ 28403 (4, 21.9-28.0 mm SL), Mucuri, rio Pau Alto in the village of Ibiranhém (17 $\left.50^{\circ} 49^{\prime \prime S} 40^{\circ} 10^{\prime} 27^{\prime \prime} \mathrm{W}\right), 31$ Oct 2004 , same collectors as the holotype. 

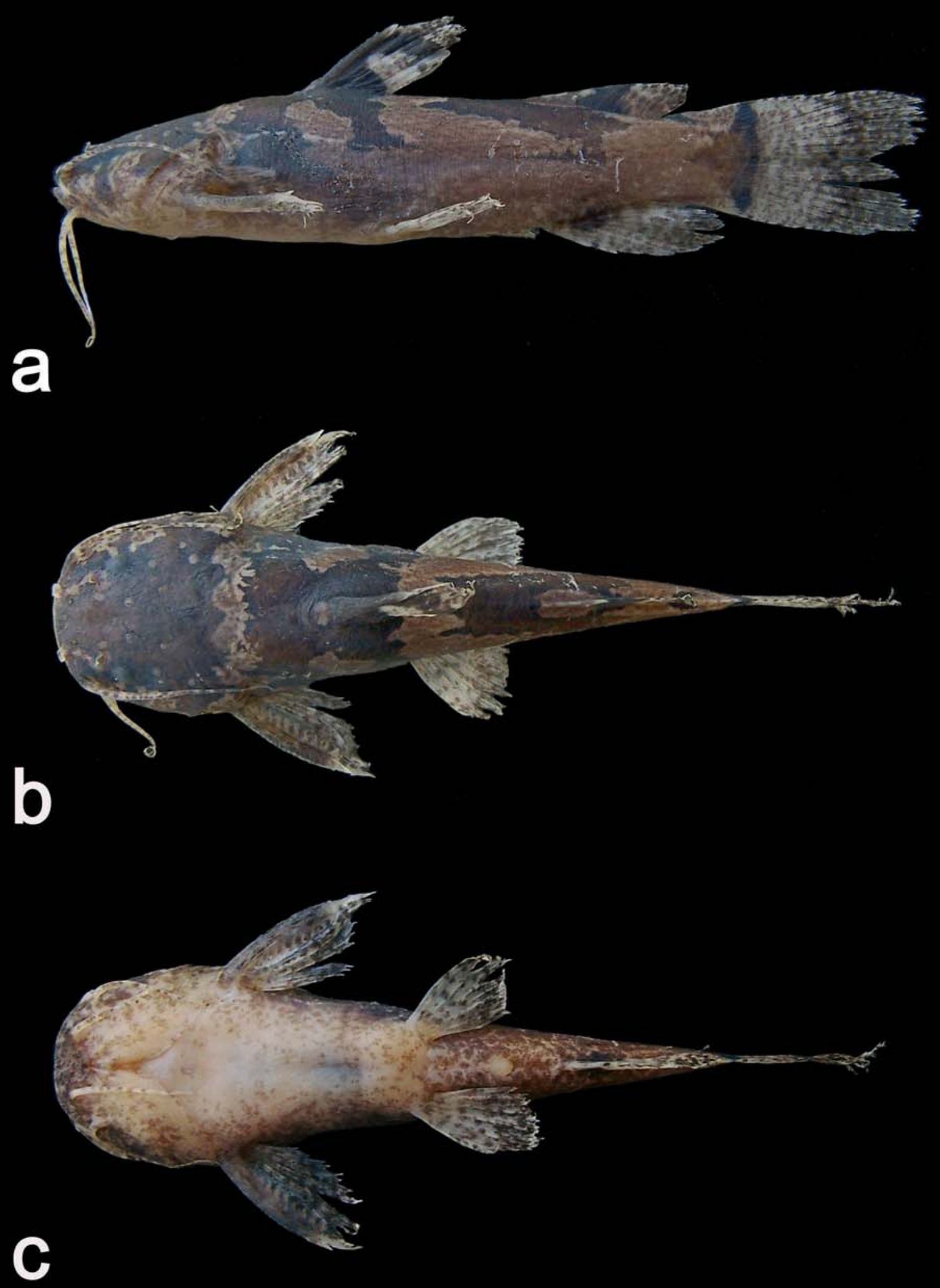

Fig. 1. Microglanis pataxo, holotype, MNRJ 28397, $39.0 \mathrm{~mm}$ SL, in a. lateral; b. dorsal; and c. ventral views. 
Diagnosis. Microglanis pataxo can be identified by the color pattern with a dark blotch beneath adipose fin not extending to anal fin and by the high number of anal fin proximal radials, 12 , shaped as rod-like thin tubes, the last one bearing a laminar extension. The new species can be also recognized by the following combination of characters: a pectoral fin spine with a bony point and bearing proportionally few serrations on posterior border of pectoral fin spine, eight to ten. Seven pleural ribs and a proportionally short head width (67.8-74.3\% in HL).

Microglanis pataxo is distinguished from M. ater by the short body depth, 13.0-17.5\% SL (vs. 25.0\%). Distinguished from M. cibelae by the short head width, 67.8-74.3\% HL ( $v s$. $78.6-81.7 \%$ ), by the proportionally shorter body depth, 13.0 $17.5 \%$ SL (vs. higher 17.2-22.5\%), caudal peduncle depth, 8.8$11.3 \%$ SL ( $v s .10 .3-14.3 \%$ ) and by the color pattern with a dark blotch beneath adipose fin not extending to anal fin ( $v s$. continuous dark bar between those fins). Distinguished from $M$. cottoides by the color pattern with a dark blotch beneath adipose fin not extending to anal fin ( $v s$. continuous dark bar between those fins); by the shorter head length, 27.0-29.0\% SL (vs. 29.3-33.2\%), by the low number of serrations on pectoral fin spine, eight to ten (vs. 13 in M. cottoides) and by the rod-like anal fin proximal radials ( $v s$. bearing laminar projections). Distinguished from $M$. eurystoma by the shorter body width, 24.4-29.0\% SL ( $v s .30 .3-34.7 \%$ ), by a shorter predorsal length, 33.0-40.2\% SL (vs. 40.4-45.7\% respectively) and by the low number of serrations on posterior border of pectoral fin spine, eight to ten (vs. 14). Distinguished from $M$. garavelloi by the larger head length, 27.0-29.0\% SL (vs. 25.0$26.6 \%$ ), by the short head width, 67.8-74.3\% HL (vs. 87.7$100.0 \%$ ), by the higher number of anal fin proximal radials, 12 (vs. 9). Distinguished from M. iheringi by the low number of pleural ribs, 7 (vs. 8) and higher number of anal fin proximal radials, 12 (vs. 11). Distinguished from M. malabarbai by the shorter head length, 27.0-29.0\% SL (vs. 29.6-33.5\%), by the shorter body width, $24.4-29.0 \%$ SL (vs. $29.3-33.1 \%$ ), by the shorter mouth width, $16.0-18.5 \%$ SL ( $v s .19 .2-22.1 \%$ ), by the color pattern with a dark blotch beneath adipose fin not extending to anal fin (vs. continuous dark bar between those fins) and by the caudal fin with scattered dark blotches ( $v s$. almost completely black with narrow white band). Distinguished from M. nigripinnis by the shorter head depth, 27.0$29.0 \%$ SL (vs. 29.0-35.0\%), by the short head width, $67.8-74.3 \%$ HL (vs. 96.2-100.0\%), by the color pattern with a dark blotch beneath adipose fin not extending to anal fin ( $v s$. continuous dark bar between those fins); by the low number of serrations on pectoral fin spine, eight to ten (vs. 12-15 in M. nigripinnis), and by the rod-like anal fin proximal radials ( $v s$. bearing laminar projections). Distinguished from $M$. parahybae by the short head width, 67.8-74.3\% HL (vs. 78.4-85.3\%), 7 pleural ribs (vs. 6) and by the rod-like anal fin proximal radials ( $v s$. bearing laminar projections). Distinguished from M. pellopterygius by the color pattern with a dark blotch beneath adipose fin not extending to anal fin (vs. continuous dark bar between those fins). Distinguished from M. poecilus by the rod-like anal fin proximal radials, 12 ( $v s$. bearing laminar projections). Distinguished from M. secundus by the color pattern with a dark blotch beneath adipose fin not extending to anal fin ( $v s$. continuous dark bar between those fins), by the low number of serrations on posterior border of pectoral fin spine, eight to ten (vs. 12) and by the pectoral fin spine with a bony point ( $v s$. pectoral fin spine bifurcated followed by a fleshy tip). Distinguished from M. variegatus by the higher number of pleural ribs, 7 (vs. 5-6), by the higher number of anal fin proximal radials, 12 (vs. 10-11) and by the higher number of vertebrae, 29 (vs. 26). Distinguished from M. zonatus by the higher number of pleural ribs, 7 (vs. 6) and higher number of anal-fin proximal radials, $12(v s .8)$.

Description. Morphometric and meristic data in Table 1. Body moderately short, head and anterior trunk depressed, becoming compressed posteriorly. Head large and dorsoventrally compressed, dorsal profile somewhat quadrangular. Dorsal profile of trunk from dorsal-fin base to caudal peduncle becoming gradually compressed laterally. Lateral profile of head from snout tip to opercular margin slightly convex; becoming straight until dorsal-fin origin. Head and anterior trunk rectangular in cross section, becoming elliptic posteriorly. Ventral profile of head and abdomen almost straight. Ventral profile of body gently curved posterior to anal fin. Caudal peduncle laterally compressed. Eyes very small, latero-superior and covered with skin. Mouth terminal, upper lip extended posterolaterally as fleshy rictal fold. Anterior nostril somewhat tubular, located on anterior border of snout, above lip; posterior nostril larger, rounded. Maxillary barbels short, reaching opercular membrane. Mental barbels four, arranged in arc along ventral surface of jaw. Inner mental barbels half length of outer mental barbels. Maxillary and mental barbels extending to pectoral fin base. Post-cleithral process slender and pointed.

Premaxilla transversely elongate, meeting its counterpart medially. Autopalatine tubular, oriented obliquely to longitudinal axis of body. Maxillary bone small, with large posterior border. Jaws of equal size. Premaxillary tooth patch not forming backwardly projecting angle. Premaxillary and dentary with four to five rows of minute conical teeth.

Dorsal-fin margin rounded, with one spine plus six branched rays. Dorsal-fin spine with anterior surface smooth and two to three small retrorse serrae on distal portion of posterior surface. Pectoral fin with one spine plus five branched rays. Pectoral-fin spine with serrae on both margins: the anterior margin serrae smaller than posterior ones. Anterior pectoral-fin margin with 13-16 serrae: those closer to base of spine retrorse, around middle of spine one or two perpendicular serrae and subsequent ones antrorse. Posterior surface of pectoral-fin spine has 8-10 retrorse serrae (Fig. 2). Pelvic-fin margin rounded, located below posterior edge of dorsal-fin. Pelvic with one unbranched plus five branched rays. Adipose-fin developed, with posterior margin free and angulose, not confluent with caudal-fin, and located above anal-fin origin. Anal-fin margin rounded, with two or three 


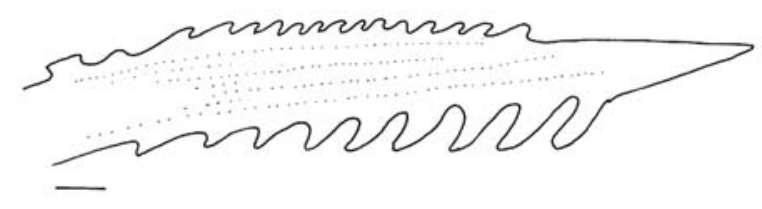

Fig. 2. Left pectoral-fin spine of Microglanis pataxo, MNRJ 28398, paratype. Dorsal view. Scale bar, $1 \mathrm{~mm}$.

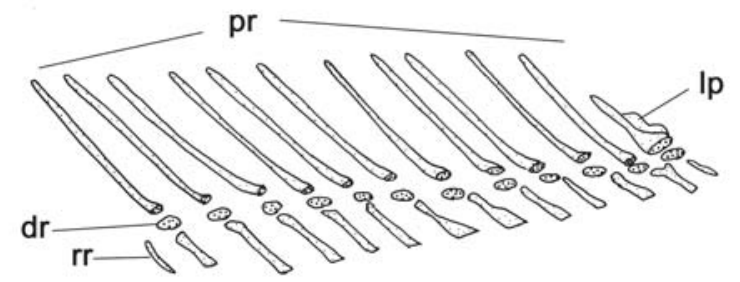

$\mathbf{a}$

b

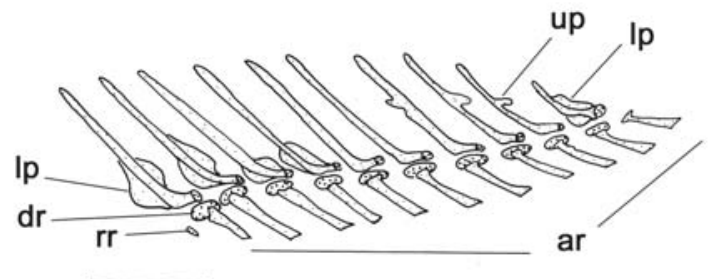

Fig. 3. Left lateral view of anal fin pterygiophores in M. pataxo (a) and M. parahybae (b). Abbreviations: ar, anal-fin rays; dr, distal radial; lp, laminar process; pr, proximal radials; rr, rudimentary ray; up, uncinate process. Scale bar, $1 \mathrm{~mm}$.

Table 1. Morphometric and meristic characters of the holotype $(\mathrm{H})$ and paratypes of Microglanis pataxo $(\mathrm{n}=25$, including the holotype) and $M$. parahybae $(\mathrm{n}=12) . \mathrm{SD}=$ standard deviation.

\begin{tabular}{|c|c|c|c|c|c|c|c|}
\hline & \multicolumn{4}{|c|}{ M. pataxo } & \multicolumn{3}{|c|}{ M. parahybae } \\
\hline & $\mathrm{H}$ & Range & Mean & SD & Range & Mean & SD \\
\hline Standard length & $\begin{array}{l}39.0 \\
\text { Perce }\end{array}$ & $21.9-39.0$ & 28.3 & 5.26 & $32.2-44.7$ & 38.6 & 4.29 \\
\hline Head length & 29.0 & $27.0-29.0$ & 27.8 & 0.57 & 25.2-30.9 & 27.9 & 1.54 \\
\hline Body width & 28.2 & $24.4-29.0$ & 26.9 & 1.35 & $24.8-31.0$ & 29.0 & 1.99 \\
\hline Interorbital width & 12.8 & $11.0-12.8$ & 11.8 & 0.50 & $10.2-12.9$ & 12.0 & 0.82 \\
\hline Dorsal spine length & 16.2 & $13.2-19.8$ & 15.2 & 1.54 & $14.0-17.7$ & 15.7 & 1.12 \\
\hline Pectoral spine length & 22.8 & $18.5-24.9$ & 20.8 & 1.42 & $19.1-24.8$ & 22.0 & 1.92 \\
\hline Predorsal length & 37.7 & $33.0-40.2$ & 37.5 & 1.95 & $36.3-40.8$ & 38.4 & 1.46 \\
\hline Prepelvic length & 49.5 & $45.9-52.5$ & 49.3 & 1.62 & $50.1-54.6$ & 52.1 & 1.66 \\
\hline Preanal length & 69.7 & $64.3-71.8$ & 68.8 & 1.95 & $68.0-74.4$ & 70.7 & 1.67 \\
\hline Caudal peduncle length & 15.9 & $13.2-18.4$ & 16.2 & 1.10 & $16.1-20.9$ & 18.1 & 1.76 \\
\hline Caudal peduncle depth & 9.5 & $8.8-11.3$ & 9.6 & 0.67 & $7.8-11.0$ & 9.2 & 0.94 \\
\hline Body depth & 15.4 & $13.0-17.5$ & 15.1 & 1.17 & $13.2-17.7$ & 16.0 & 1.26 \\
\hline Head width & 20.5 & $18.9-21.0$ & 19.9 & 0.54 & $20.8-24.5$ & 23.1 & 1.03 \\
\hline Mouth width & $\begin{array}{c}18.5 \\
\text { Per }\end{array}$ & $\begin{array}{l}16.0-18.5 \\
\text { cents of he }\end{array}$ & $\begin{array}{l}17.1 \\
\text { ad lengt }\end{array}$ & $\begin{array}{l}0.57 \\
\text { th }\end{array}$ & $17.4-20.3$ & 18.7 & 1.12 \\
\hline Orbital diameter & 9.7 & $8.7-14.1$ & 11.2 & 1.37 & $9.0-14.8$ & 11.9 & 1.76 \\
\hline Snout length & 40.7 & $36.0-49.2$ & 41.1 & 1.89 & $36.2-41.3$ & 38.4 & 1.97 \\
\hline Interorbital width & 44.2 & $39.2-45.5$ & 42.5 & 1.86 & $38.9-45.5$ & 42.9 & 1.94 \\
\hline Head width & 70.8 & $67.8-74.3$ & 71.6 & 1.99 & $78.4-85.3$ & 82.9 & 1.98 \\
\hline Mouth width & 63.7 & $\begin{array}{r}58.2-64.7 \\
\text { Ray Cou }\end{array}$ & $\begin{array}{l}61.3 \\
\text { unts }\end{array}$ & 1.99 & 64.8-71.4 & 66.9 & 1.97 \\
\hline Total dorsal fin & i,6 & $\mathrm{i}, 6$ & 7.0 & 0.00 & $\mathrm{i}, 6$ & 7.0 & 0.00 \\
\hline Total pectoral fin & i,5 & $\mathrm{i}, 5$ & 6.0 & 0.00 & i,5-6 & 6.5 & 0.52 \\
\hline Total ventral fin & i,5 & $\mathrm{i}, 5$ & 6.0 & 0.00 & i,5 & 6.0 & 0.00 \\
\hline Total anal fin & iii,8 & ii-iii,7-9 & 10.7 & 0.56 & iii-iv,7-9 & 11.4 & 1.12 \\
\hline Total caudal fin & $\mathrm{i}, 13, \mathrm{i}$ & i,13-14,i & 15.1 & 0.33 & $\mathrm{I}, 12-14, \mathrm{i}$ & 15.1 & 0.54 \\
\hline
\end{tabular}

unbranched rays, plus one anteriormost reduced ray and seven to nine branched rays, not reaching caudal-fin base. Nine branched anal-fin rays rare, found only in one specimen. 12 rod-like, thin anal-fin proximal radials, last one short and laminar (Fig. 3). Twelve distal radials completely cartilaginous. Caudal fin slightly forked, its upper lobe longer than lower, with 13-14 branched rays; principal rays 7+8; upper procurrent 15; lower procurrent nine. Total vertebrae 29. Seven pleural ribs becoming progressively small antero-posteriorlly.

Osteological features. Cranial roof somewhat triangle shaped (Fig. 4). Surface rough, ornamented with small ridges and pits. One single wide cranial fontanel placed between mesethmoid and frontals. Mesethmoid constricted before anterior cranial fontanel, divergent cornua create broad, shallow median cleft; premaxillaries held underneath it through synchondral articulation. Large lateral ethmoids form lateral wings laterally to mesethmoid and frontals. Frontals sutured behind cranial fontanel. Each frontal bone anteriorly narrow and posteriorly expanded, sutured to sphenotic and parietosupraoccipital. Sphenotic bone narrow, forming lateroposterior margin of the skull roof with pterotic and posttemporosupracleithum. Sphenotic and pterotic bearing hyomandibula facet on their ventral surface. Sphenotic synchondrally joined to prootic and pterosphenoid on cranial floor, and sutured to frontal, parieto-supraoccipital and pterotic on cranial roof. Pterotic wider than sphenotic and sutured to it and to parieto-

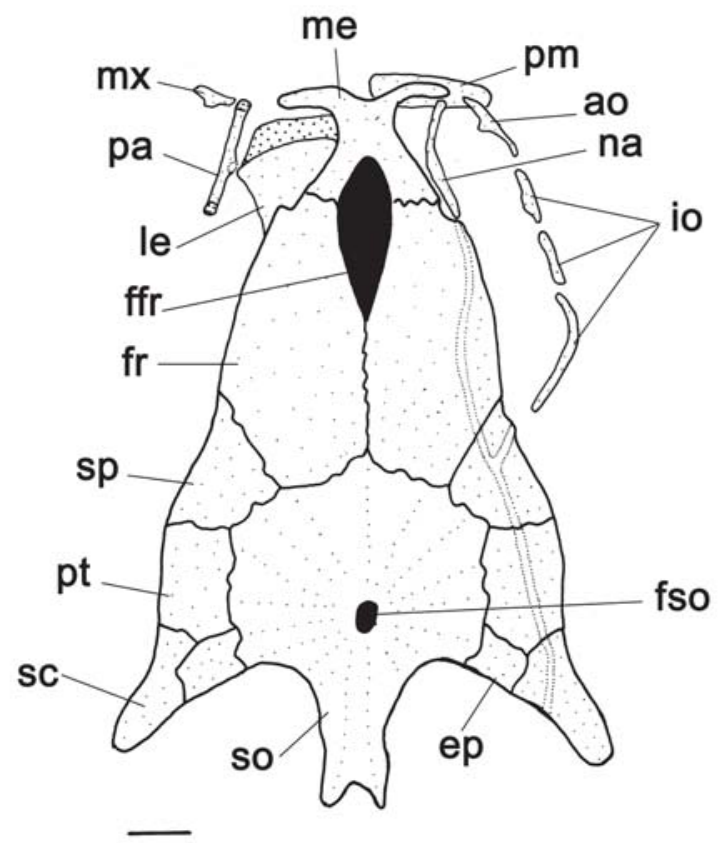

Fig. 4. Cranium of Microglanis pataxo, MNRJ 28398, paratype. Dorsal view. Abbreviations: ao, antorbital; ep, epioccipital; fr, frontal; ffr, frontal fontanell; fso, parieto-supraoccipital fontanel; io, anterior, middle and posterior infraorbitals; le, lateral ethmoid; mx, maxilla; na, nasal; pa, autopalatine; pm, premaxilla; pt, pterotic; sc, posttemporosupracleitrum; so, parietosupraoccipital; sp, sphenotic. Scale bar, $1 \mathrm{~mm}$. 
supraoccipital, epiotic, and posttemporosupracleithrum on cranial roof. Synchondrally joined to prootic and exoccipital on cranial floor. Parieto-supraoccipital moderately large, sutured dorsally to frontals, sphenotics, pterotics, and epioccipitals. Posteroventrally sutured to exoccipitals. Minute parieto-supraoccipital fontanel represented by single posterior opening. Caudally to fontanel, parieto-supraoccipital crest extended medially. Tubular ossified nasal bone between mesethmoid cornua and lateral ethmoid. Nasal slightly curved, free bone, ligamentously attached to lateral margins of frontals and mesethmoid.

Floor and lateral walls of cranium as for catfishes in general. Vomer ovoid and broad, between cartilaginous wings of lateral ethmoid and in contact with mesethmoid dorsally. Parasphenoid with narrow anterior limb sutured to vomer and with wide lateral projection immediately above foramen for trigeminofascialis nerve. Orbitosphenoid large, sutured to frontals and with broad synchondral joint to lateral ethmoid. Prootic somewhat large making short sutural and synchondral joint with pterosphenoid. Wide foramen for trigeminofascialis nerve between prootic, parasphenoid, and pterosphenoid. Exoccipitals forming lateroposterior corner of cranium, bearing synchondral joints with basioccipital, prootic, and pterotic. Single basioccipital broad and compact, sutured lateroanteriorlly to parasphenoid and synchondrally joined laterally to prootics and exoccipitals. Foramen magnum bordered by basioccipital, exoccipital, and parieto-supraoccipital.

Suspensorium with broad laminar hyomandibula, anteriorly sutured to elongated rectangular metapterygoid. Quadrate thick, articulated to metapterygoid and hyomandibula through cartilage. Preopercle sutured to ventral margins of both quadrate and hyomandibula. No suprapreopercle present. Opercle laminar and broadly triangular (Fig. 5).

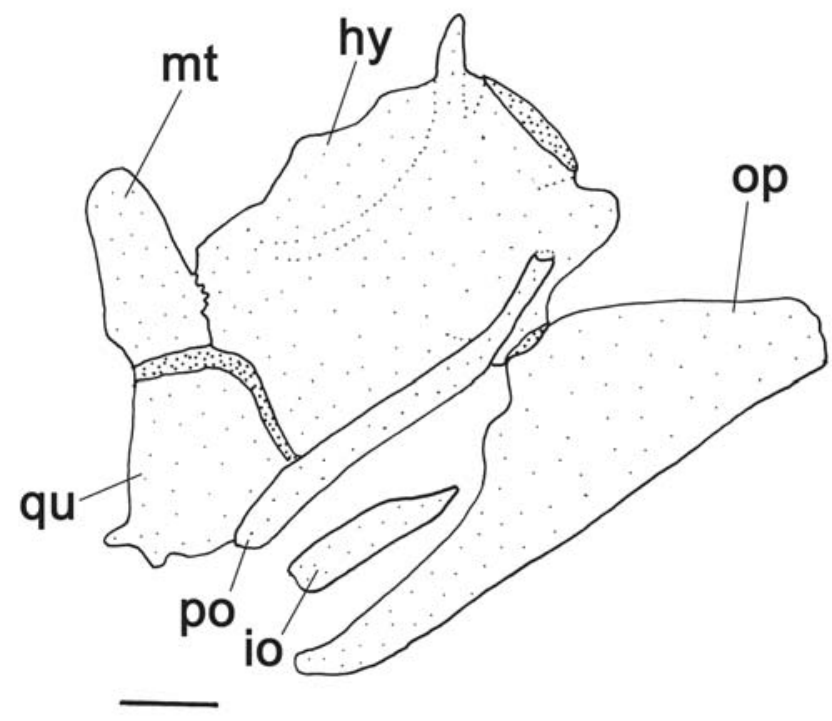

Fig. 5. Left suspensorium of Microglanis pataxo, MNRJ 28398, paratype. Lateral view. Abbreviations: hy, hyomandibula; io, interopercle; mt, metapterygoid; op, opercle; po, preopercle; qu, quadrate. Scale bar, $1 \mathrm{~mm}$.
Hyoid arch with small ventral hypohyal, well developed anterior ceratohyal and triangular posterior ceratohyal. Ten branchiostegal rays articulated with hyoid arch: six with anterior ceratohyal, two with interceratohyal cartilage between bones, and two with posterior ceratohyal. Posteriormost brachiostegal rays, on posterior ceratohyal, largest, expanded and curved (Fig. 6).

Urohyal with expanded, narrowly paired lateral processes and short pointed posterior processes. Basibranchial $1 \mathrm{ab}-$ sent; basibranchial 2 plus 3 forming cartilaginous rod with anterior tip reaching dorsal surface of ceratohyal and posterior, osseous, tip nearly in contact with basibranchial 4 . Basibrachials 2 plus 3 rod bordered laterally by cartilaginous head of hypobranchials 2 and 3. Basibranchial 4 bordered anteriorly by cartilaginous hypobranchials 3 , laterally by cartilaginous head of ceratobranchials 4 and posteriorly by cartilaginous head of ceratobranchials 5. Hypobranchials 1 and 2 osseous, elongate, trapezoid, contoured with cartilage along its lateral and posterior borders. Hypobranchial 3 completely cartilaginous and approximately trapezoidal. Hypobranchial 4 absent. Five ceratobranchials present, mostly ossified, with cartilage on their extremities. First ceratobranchial giving support to single row of four finely-shaped elongated rakers. Second ceratobranchial also with single row of rakers. Third, fourth and fifth ceratobranchials with two rows of short rakers. Fifth ceratobranchial expanded posteromedially to support lower pharyngeal toothplate dorsally, with finely-shaped conical teeth arranged in four or five rows. Five epibranchials, first four largely ossified; except for its cartilaginous extremities. Epibranchials 1 and 2 rod-like, with short rakers arranged in one row. Epibranchial 3 with elongate posterior uncinate process. Epibranchial 4 broad, somewhat convex posteriorlly. Epibranchial 5 completely cartilaginous, placed between posterior cartilaginous tips of epibranchial 4 and ceratobranchial 4. Pharyngobranchial 1 absent. Pharyngobranchial 2 short, completely cartilaginous, placed between anterior cartilaginous tips of epibranchials 1 and 2 and subsequent pharyngobranchial. Pharyngobranchial 3 elongate, ossified, with well developed posterior border. Pharyngobranchial 4 ossified, giving support to upper pharyngeal tooth plate, with robust conical teeth arranged in four to five rows (Fig. 7).

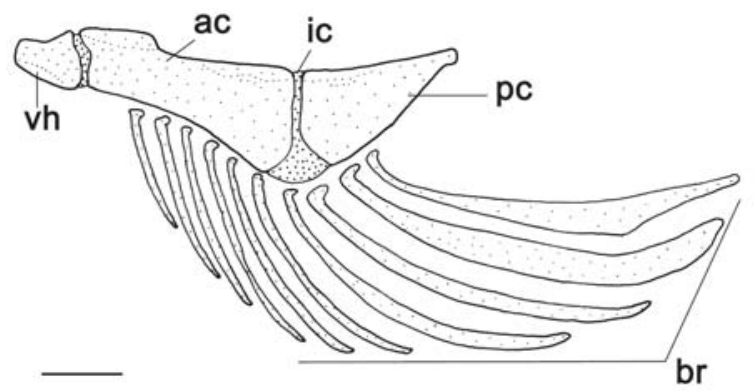

Fig. 6. Right hyoid arch of Microglanis pataxo, MNRJ 28398, paratype. Medial view. Abbreviations: ac, anterior ceratohyal; br, branchiostegal rays; ic, interceratohyal cartilage; pc, posterior ceratohyal; vh, ventral hypohyal. Scale bar, $1 \mathrm{~mm}$. 


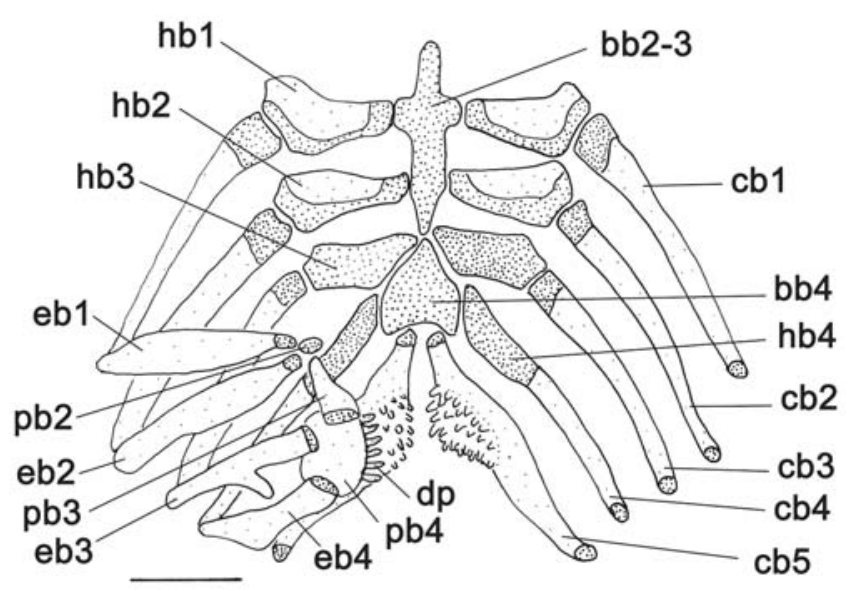

Fig. 7. Branchial skeleton of Microglanis pataxo, MNRJ 28398, paratype. Dorsal view. Abbreviations: bb2-3, basibrachial 2 plus 3; bb4, basibrachial 4; cb1 to cb5, ceratobranchials 1 to 5 ; dp, dentigerous plate; eb1 to eb4, epibranchials 1 to 4 ; hb1 to hb4, hypobranchials 1 to 4 ; pb2 to pb4, pharyngobranchials 2 to 4 . Scale bar, $1 \mathrm{~mm}$.

Antorbital slim, with pronounced anterior process. Infraorbitals thin and tubular, almost reduced to their canalicular portions. Three canal bones: anterior and middle about same size; posteriormost one longest. Infraorbital laterosensory canal branch bearing four to five paired pores: first, anterior, infraorbital pore close to antorbital and last, posterior, infraorbital pore close to sphenotic opening for laterosensory canal. Supraorbital laterosensory canal branch with seven or eight paired pores; first one close to anterior nasal opening; last one close to supracleithrum border. Preopercle-mandibular laterosensory canal branch with eight to nine paired pores, anteriormost four associated with lower lip. First pore near

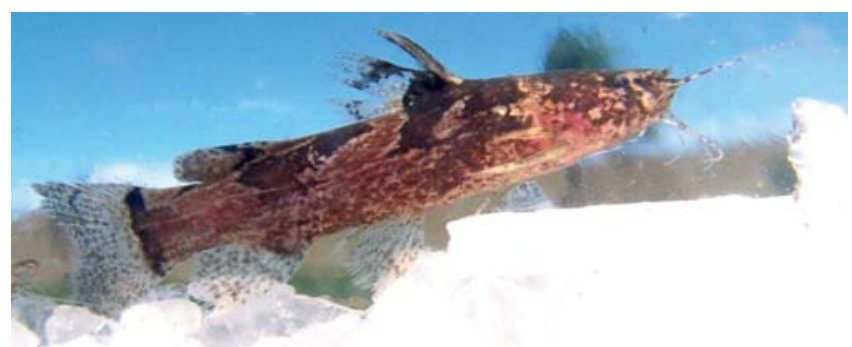

Fig. 8. Microglanis pataxo, live specimen in a field aquarium shortly after collection.

mandibular symphysis and last one next to preopercular canal opening. Lateral line on body interrupted, with seven pores anterior to origin of dorsal fin; no isolated pores posteriorly.

Color in alcohol. Head almost completely dark dorsally, with lighter areas below eyes and around cephalic lateral line pores. Conspicuous, transverse, light band just behind head, crossing pectoral-fin base, as typically for Microglanis species. First dark blotch shaped as large "x", around dorsal-fin base in dorsal view; and second one between dorsal and adipose fins. Adipose fin with characteristic dark band on its anterior or middle portion. Ventral region of head with dark melanophores, concentrated around mental barbels, and becoming sparse towards belly. Dorsal-fin base and spine dark, its distal portion crossed by large dark bar. Caudal peduncle with dark patch of coloration beginning in its central portion becoming larger towards its margins, triangle shaped, and ending in transverse dark bar onto caudal-fin base. Caudal fin with scattered dark melanophores and narrow dark bar along contour of each lobe, near its tip.

Live coloration. Ground color light brown with irregular dark areas on head, dorsal fin and between dorsal and adipose
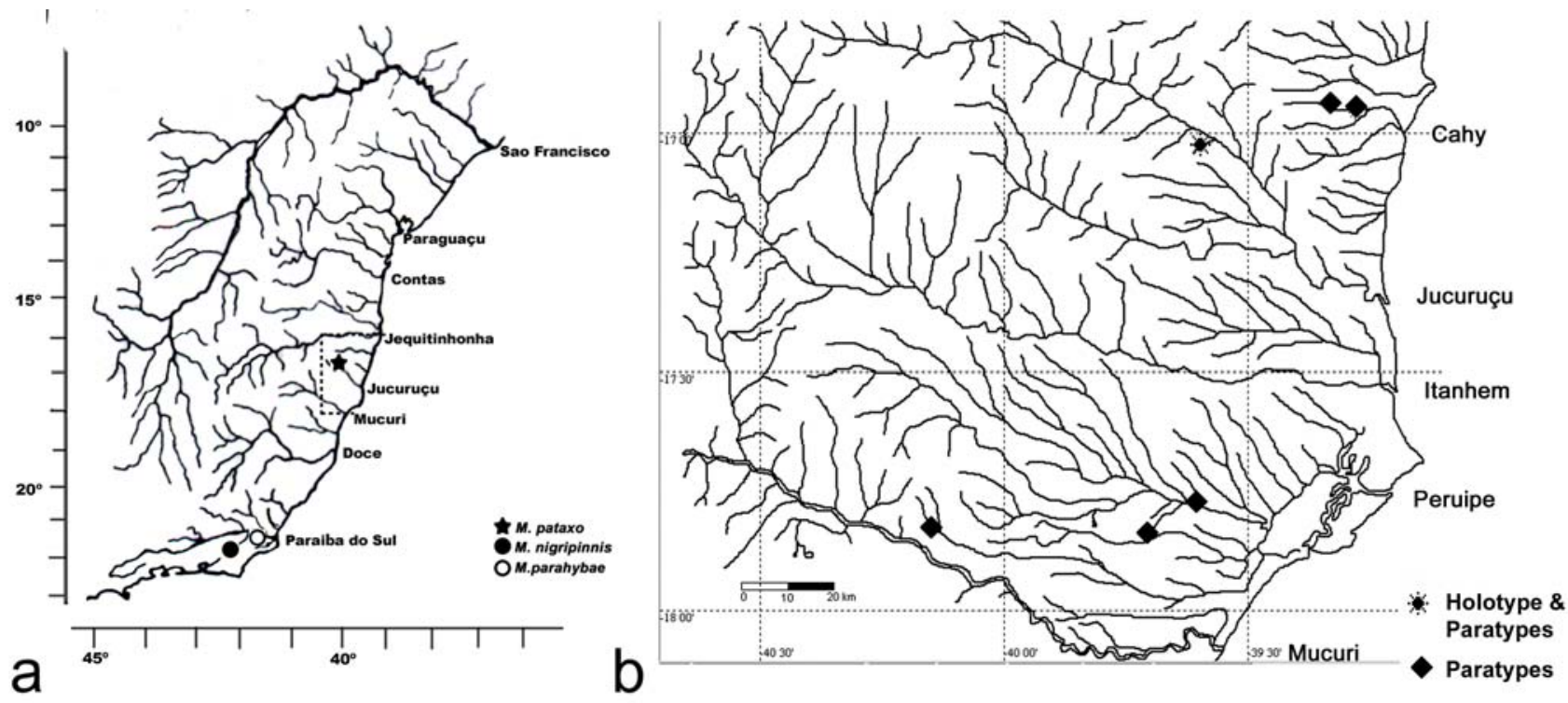

Fig. 9. a. Drainage map of eastern Brazil between rio São Francisco and rio Paraíba do Sul illustrating the distribution of the Microglanis species in the area. Dotted line indicates the study area. Symbols may represent more than one locality. b. Detail of collecting localities of Microglanis pataxo in the study area, between the rio Mucuri and rio Jequitinhonha. 
fins. Caudal-fin base with conspicuous dark bar. Ventral surface of body lighter, with melanophores distributed on belly. Most fins hyaline with scattered melanophores over fin rays and membranes; dorsal fin with an irregular dark stripe along its longitudinal axis; adipose fin light brown with small patch of dark pigmentation near to its dorsal margin (Fig. 8).

Distribution. Microglanis pataxo is the first record of the genus in northeastern Brazilian rivers. The new species was found in coastal drainages of southeastern Bahia, in the drainages of rio Peruípe, rio Jucuruçu, and rio Cahy (Fig. 9).

Etymology. The specific name honors the Pataxó native indigenous people, who live in the neighbourhoods of the distribution area of the new Microglanis species.

Ecological notes. The river systems in southern Bahia cross a plain to undulate relief with sediments from Tertiary to Quaternary, responsible for the formation of "tabuleiros", the regional name in reference to the vast open plain left on landscape. Geologically those coastal "tabuleiros" belongs to the "Formação Barreiras", dated from the Pliocene, extending from the coast up to $110 \mathrm{~km}$ inland from Ilhéus, Bahia, to the mouth of rio Doce, in Espírito Santo (SRH, 1996). The whole study area was originally covered by the Atlantic Forest, but presently the vegetation around river drainages show different degrees of environmental conservation (MMA, 2000). At the rio Peruípe the vegetation was changed to eucalyptus tree groves, reminiscent of riparian vegetation only on river banks. The upper portion of rio Jucuruçu, called rio do Prado, is one of the heaviest impacted river system, being much deforested and occupied with pastures. The rio Palmares, a tributary of the rio Cahy, passes somewhat closer to the Pataxó indigenous village of Águas Belas, and the catfishes were captured downstream from the Palmares village. The small rio Cahy basin still has patches of original and secondary vegetation and riparian covering along the upper portions of its streams being partially protected in an environmental preservation area, the Parque Nacional do Descobrimento. The new Microglanis species was collected in the middle course of shallow waters, at a depth of 1 to $1.5 \mathrm{~m}$. None of them were captured in the upper portions. Those catfishes were found in moderate flowing sections of the rivers, with sandy or gravel bottom. The environments were moderately vegetated and the water clear or brown (Fig. 10). In the stomach of two examined females (MNRJ 28398, 33.8 mm SL; MNRJ 28401, $23.9 \mathrm{~mm} \mathrm{SL}$ ), it was possible to identify small aquatic insect larvae and pupae. The $33.8 \mathrm{~mm}$ individual was a mature female, with large eggs in its gonads.

\section{Key to species of Microglanis from coastal drainage between} Rio de Janeiro and Bahia states

1. Head width moderately large, ranging between $67.8-87.0 \%$ of HL; head and body color pattern mottled in light and dark brown, pectoral, pelvic, and adipose fins light colored or hyaline .
1 '. Head width very large, ranging between $96.2-100.0 \%$ of SL; head and body color pattern mostly black or dark brown, pectoral, pelvic, and adipose fins dark colored M. nigripinnis

(Fig. 11a; rio Macacu and rio São João coastal drainages)

2. Head width comparatively large (78.4-85.3\% of HL), pleural ribs 6 .................................................. M. parahybae

(Fig. 11b; rio Paraíba do Sul drainage, coastal drainages of Rio de Janeiro and rio Doce drainage)

2'. Head width comparatively narrow (67.8-74.3\% of HL), pleural ribs 7 . M. pataxo

(Fig. 11c; coastal river drainages of southeastern Bahia)

\section{Discussion}

The new catfish is recognized as Microglanis because it has the premaxillary bands of teeth with lateral margin rounded, a mesocoracoid arch filamentous, and body size smaller than $80 \mathrm{~mm}$, characters diagnostic for the genus as stated by Shibatta (2003a).

The distinctive characters of the new species in relation to all Microglanis species is given in the diagnosis section. The recognition of $M$. pataxo from its geographically closest relatives deserves some comments. There are two Microglanis species recorded from coastal drainage between Rio de Janeiro and Bahia states: M. nigripinnis and M. parahybae. Microglanis nigripinnis is the most robust Microglanis species in the area. The color pattern promptly differentiates this species, as it is mostly black colored, with almost dark fins (Fig. 11a) (Bizerril \& Perez-Neto, 1992). Besides coloration, it is quite distinct by its broad head almost as long as large (head width $96.2-100.0 \%$ in HL); deeper body depth (19.0-22.9\% SL), nine branched anal-fin rays and 14 branched caudal-fin rays. In comparison to $M$. nigripinnis, $M$. pataxo has a different body coloration with alternate patches of irregular dark and light blotches and fins mostly hyaline, except for the dorsal fin with dark bands (Fig. 11c). Microglanis pataxo has a slender head, longer than larger (head width 67.8-74.3\% in HL), body depth short (13.0-17.5\% SL), branched anal-fin rays mainly 7 or 8 , rarely 9 , and 13-14 branched caudal-fin rays.

Microglanis parahybae is recognized by a pale area between pelvic and anal fins; as well as dorsal and caudal fins with dark bands (Fig. 11b) (Steindachner, 1880; Miranda Ribeiro, 1911; Caramaschi, 1991). Microglanis parahybae is herein recognized as having a highly variable color pattern, with some specimens darker resembling $M$. nigripinnis, and others with light and dark blotches such as in $M$. pataxo. The distinction between $M$. pataxo and $M$. parahybae is based on a comparatively wider head (78.4-85.3\% of HL vs. 67.8$74.3 \%$ in M. parahybae); pectoral-fin spine with proportionally larger serrations on posterior margin and few in number, eight to ten (vs. small serrations and numerically more, 14-22, in M. parahybae); and pleural ribs 7 (vs. 6 in M. parahybae). In comparison to both species in the area, M. pataxo is distinct regarding the short head width $(67.8-74.3 \%$ in HL vs. 


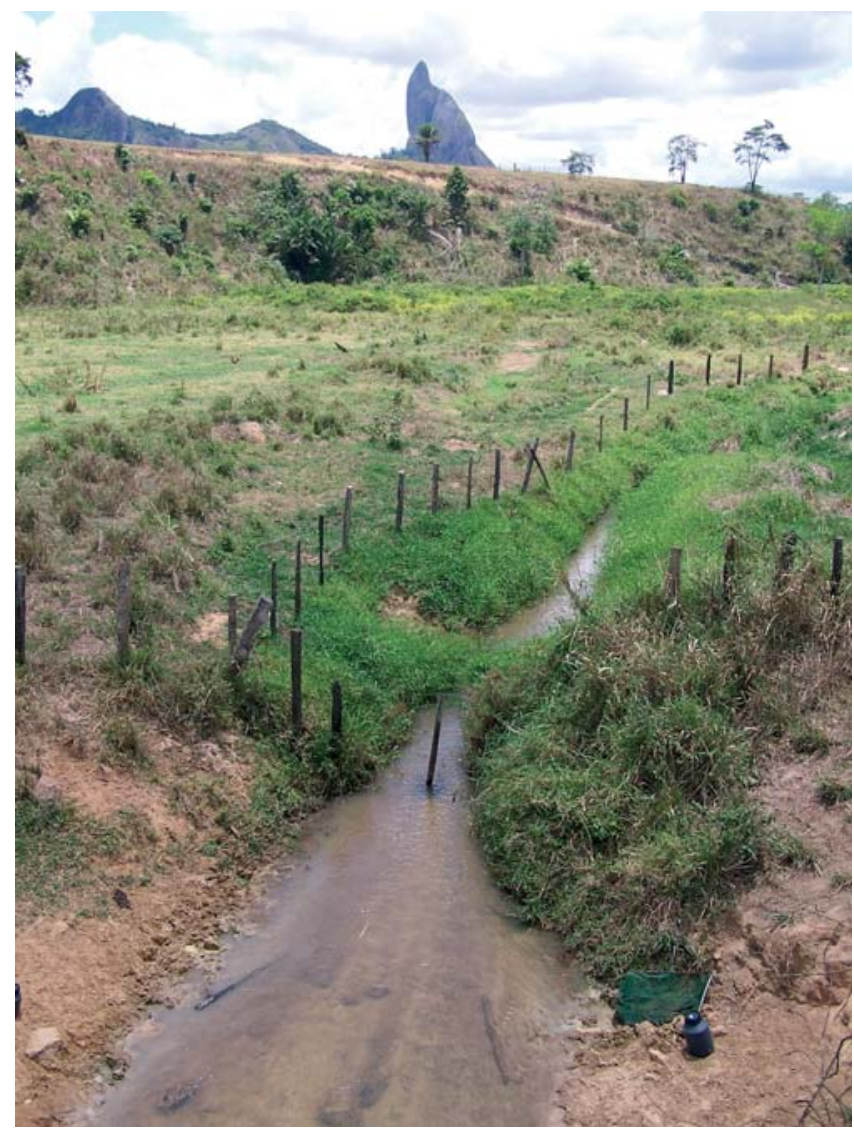

Fig. 10. Jundiar creek, Itamaraju, southern Bahia, type-locality of Microglanis pataxo.

78.4-85.3\% in M. parahybae as stated above and $96.2-100.0 \%$ in M. nigripinnis), and regarding the low number of 8-10 retrorse serrae in the posterior border of pectoral fin spine ( $v s$. 14-22 retrorse serrae in M. parahybae and 12-15 in $M$. nigripinnis).

Microglanis pataxo is quite similar to M. parahybae regarding some osteological features, such as the cranium, suspensorium, hyoid arch, and branchial skeleton. Regarding arrangement and number of anal-fin pterygiophores, $M$. pataxo has slender proximal radials, while its morphologically closest relative, $M$. parahybae, has broader ones. In M. parahybae there are laminar processes on the anterior proximal radials and uncinate process on the posterior ones, a condition found to be present in all the cleared and stained specimens examined, while in $M$. pataxo the radials are simple tubes (compare Figs. 3a and 3b). Anal-fin proximal radials bearing laminar projections were also recognized in radiographs of M. cottoides and M. poecilus, differing from the slender, rodlike, anal-fin proximal radials in M. pataxo. Osteological information in literature regarding the Microglanis species is available for M. cottoides and M. eurystoma in Guazzelli (1997), who observed a short supraoccipital process reaching the predorsal plate; a narrow anterior fontanel and a posterior fontanel opening as a pore. Those characters are in conformity of what was observed for the $M$. pataxo cranium.
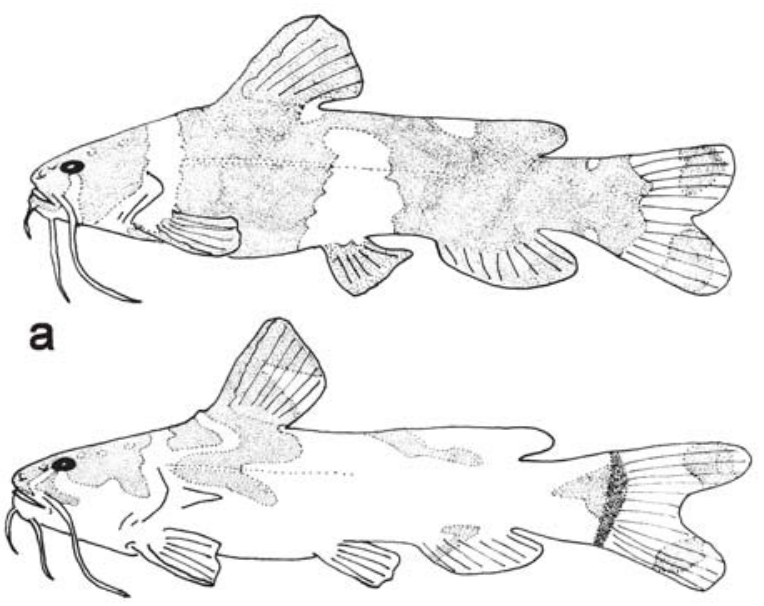

b

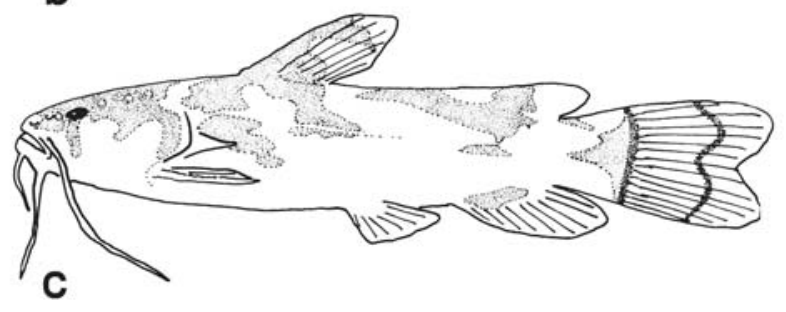

Fig. 11. Schematic drawing illustrating the general coloration pattern in Microglanis species found in the Eastern Atlantic Basin. a. Microglanis nigripinnis; b. M. parahybae; c. M. pataxo.

Comparative material. Microglanis cibelae: MNRJ 14177, 2; MNRJ 19173, 2. Microglanis cottoides: CAS 40864, 1 (R); MNRJ 24320, 1; MNRJ 26112, 3; MNRJ 27617, 1; USNM 279533, 1 (R); USNM 285838, 2 (R). M. garavelloi: MNRJ 19198, 2. M. iheringi: FMNH 35350, 1, holotype (P); USNM 121985, 1 (R); USNM 348688, 2 (R); USNM 349417, 1 (R); CAS 47731, 1 (R). $M$. pellopterygius: ANSP 130437, 1, holotype, (P). M. poecilus: CAS 63679,2 , paratypes (R); FMNH 46365, 1, holotype, (P); USNM 66123, 1 (R); USNM 88278, 1 (R); USNM 100787, 1 (R); USNM 163164, 1 (R);USNM 225421, 2 (R). M. parahybae: MNRJ 11789 , 5; MNRJ 14178, 2; MNRJ 15912, 1; MNRJ 15958, 1; MNRJ 15961, 2, 1 c\&s; MNRJ 15992, 2; MNRJ 15996, 1; MNRJ 16001, 1; MNRJ 17536, 1; MNRJ 18010, 1; MNRJ 18028, 1; MNRJ 18048, 1; MNRJ 19970, 7; MNRJ 22962, 3; MNRJ 22981, 1; MNRJ 22999, 23; MNRJ unnumbered, 4, 2 c\&s; USNM 318207, 2 (R); USNM 318211, 2 (R); USNM 318225, 2 (R). M. variegatus: CAS 17971, 1, holotype, (P) and (R); USNM 83516, 1 (R). $M$. zonatus: CAS 17970, 1, holotype, (P) and (R). Microglanis sp. MNRJ 13441, 10; MNRJ 13443, 2; MNRJ 14178, 2; MNRJ 18048,1; MNRJ 18596, 1; MNRJ 21312, 1.

\section{Acknowledgments}

We wish to thank our colleagues at the Setor de Ictiologia of the Museu Nacional, and in special Gustavo Nunan, Paulo Buckup, and Priscila Gomes. We are grateful to Sandra Raredon and Jon Fong for the radiographies of specimens and also to the image bank of the All Catfish Species Inven- 
tory webpage. Funding for field work was provided by the All Catfish Species Inventory, supported by the National Science Foundation, NSF DEB-0315963. We are indebted to the Instituto Brasileiro do Meio Ambiente e dos Recursos Naturais Renováveis (IBAMA) for the regional collection permits in the study area.

\section{Literature Cited}

Arratia G. 2003. Catfish head skeleton. An overview. Pp. 20-46 In: Arratia G., B. G. Kapoor, M. Chardon \& R. Diogo (Eds). Catfishes. Science Publishers, Enfield, 487p.

Arratia, G. \& L. Huaquin. 1995. Morphology of the lateral line system and of the skin of diplomystid and certain primitive loricarioid catfishes and systematic and ecological considerations. Bonner Zoologische Monographien, 36: 1-110.

Bertaco, V. A. \& A. R. Cardoso. 2005. A new species of Microglanis (Siluriformes: Pseudopimelodidae) from the rio Uruguay drainage, Brazil. Neotropical Ichthyology, 3(1): 61-67.

Bizerril, C. R. S. F. \& P. R. Perez-Neto. 1992. Description of a new species of Microglanis (Siluroidei, Pimelodidae) from eastern Brazil. Revue Française d'Aquariologie et Herpetologie, 18(4): 97-100.

Caramaschi, E. P. 1991. Levantamento da ictiofauna do rio Paraíba do Sul e ciclo reprodutivo das principais espécies, no trecho compreendido entre Três Rios e Campos. Volume I Levantamento e Distribuição da Ictiofauna. Furnas Centrais Elétricas S. A., convênio ENGEVIX, FUJB, UFRJ, Rio de Janeiro. 275p.

Eigenmann, C. H. 1912. The freshwater fishes of British Guiana, including a study of the ecological grouping of species, and the relation of the fauna of the plateau to that of the lowlands. Memoirs of the Carnegie Museum, 5(1): 1-578.

Guazzelli, G. M. 1997. Revisão das espécies de Pimelodella Eignmann \& Eigenmann, 1988 (Teleostei: Siluriformes: Pimelodidae) dos sistemas costeiros do sul e sudeste do Brasil. Unpubl. M.Sc. Thesis, Pontifícia Universidade Católica do Rio Grande do Sul, Porto Alegre. 150p.

Malabarba, L. R. \& J. K. F. Mahler, Jr. 1998. Review of the genus Microglanis in the rio Uruguay and coastal drainages of southern Brazil (Ostariophysi: Pimelodidae). Ichthyological Exploration of Freshwaters, 9(3): 243-254.
Mees, G. F. 1974. The Auchenipteridae and Pimelodidae of Suriname (Pisces, Nematognathi). Zoologische Verhandelingen, 132: 1256.

MMA - Ministério do Meio Ambiente. 2000. Avaliação e ações prioritárias para a conservação da biodiversidade da Mata Atlântica e Campos Sulinos. Ministério do Meio Ambiente, Conservation International do Brasil, Fundação SOS Mata Atlântica, Fundação Biodiversitas, Instituto de Pesquisas Ecológicas, Secretaria do Meio Ambiente do Estado de São Paulo, Instituto Estadual de Florestas de Minas Gerais. Brasília, 40p.

Miranda Ribeiro, A. 1911. Fauna braziliense. Peixes. Tomo IV (A) [Eleutherobranchios Aspirophoros.] Arquivos do Museu Nacional do Rio de Janeiro, 16: 1-504.

Shibatta, O. A. 1998. Sistemática e evolução da família Pseudopimelodidae (Ostariophysi, Siluriformes), com a revisão taxonômica de gênero Pseudopimelodus. Unpubl. Ph. D. Dissertation. Universidade Federal de São Carlos, São Carlos. $357 \mathrm{p}$.

Shibatta, O. A. 2003a. Phylogeny and classification of 'Pimelodidae'. Pp. 385-400. In: G. Arratia, B. G. Kapoor, M. Chardon \& R. Diogo (Eds.). Catfishes. Science Publishers, Enfield, 487p.

Shibatta, O. A. 2003b. Family Pseudopimelodidae. Pp. 401-405. In: R. E. Reis, S. O. Kullander \& C. J. Ferraris (Eds.). Checklist of the freshwater fishes of South and Central America. Edipucrs, Porto Alegre, 729p.

Shibatta, O. A. \& R. C. Benine. 2005. A new species of Microglanis (Siluriformes: Pseudopimelodidae) from upper rio Paraná basin, Brazil. Neotropical Ichthyology, 3(4): 579-585.

SRH - Secretaria de Recursos Hídricos. 1996. Plano diretor de recursos hídricos das bacias do extremo sul. Volume 6. Documento síntese. Ministério do Meio Ambiente, MMA/ Brasil.

Steindachner, F. 1880. Zur Fisch-Fauna des Cauca und der Flüsse bei Guayaquil. Denkschrift Akademie der Wissenschaften in Wien, 42: 55-104.

Taylor, W. R. \& G.C. van Dyke. 1985. Revised procedures for staining and clearing small fishes and other vertebrates for bone and cartilage study. Cybium, 9(2): 107-119.

Received September 2005 Accepted March 2006 